\title{
The São Francisco sediment delivery system: major implications for delta development, sediment transfer to the deep sea and impacts of anthropogenic river regulation
}

\author{
José Maria Landim Dominguez - Federal University of Bahia - landim@ufba.br
}

Copyright 2021, SBGf - Sociedade Brasileira de Geofísica.

This paper was prepared for presentation during the $17^{\text {th }}$ International Congress of the Brazilian Geophysical Society held in Rio de Janeiro, Brazil, $16-19$ August 2021.

Contents of this paper were reviewed by the Technical Committee of the $17^{\text {th }}$ International Congress of the Brazilian Geophysical Society and do not necessarily represent any position of the SBGf, its officers or members. Electronic reproduction or storage of any part of this paper for commercial purposes without the written consent of the Brazilian Geophysical Society is prohibited.

\begin{abstract}
The São Francisco is the fourth longest river in South America. Actually, the São Francisco comprises two rivers. The upper and middle catchment are located entirely within the São Francisco craton. In this sector the river flows mostly on a very flat surface extending from Pirapora to Sobredinho. The alluvial plain reaches more than $10 \mathrm{~km}$ in width and there has been extensive alluvial and aeolian sedimentation. This sector acts as an important terrestrial sediment sink. When the river exits the craton, its course is entrenched and characterized by rapids and waterfalls and there is almost no sediment accumulation. This suggests that there is possibly a decoupling between these two sectors which might have had important implications to the construction of the homonymous delta and canyon, and to the impacts of dam construction along the river. The river has built an important wavedominated delta whose construction was punctuated and took place during episodes of higher river discharges coincident with Bond events 4, 2 and 1 and periods of higher precipitation in the river basin. The last major episode of delta construction apparently ended at approximately $1.0 \mathrm{ka} \mathrm{BP}$. Since that time, riverine sediment input has been just sufficient to maintain the shoreline. A decrease in rainfall in combination with river regulation, particularly after 1985, triggered extensive erosion at the delta shoreline. This erosion was not caused by sediment retention behind the major dams but instead resulted from changes in the backwater/drawdown effects deriving from river regulation. The delta (both the delta plain and the shelf clinoform) was constructed entirely within a bathymetric depression that surrounds the head of the São Francisco canyon (SFC). This depression created additional accommodation space allowing for the accumulation of a complete sedimentary record of the last deglaciation. We hypothesize that the origin and evolution of the SFC is associated with three main factors: (i) breaching by the canyon head of thick carbonates rimming the shelf break; (ii) development of the shelf depression referred above; and (iii) major continental drainage reorganization. Continuous canyon-river connection was ensured by this shelf depression, which helped funnel siliciclastic sediments to the canyon and precluded lateral changes to the lower river trunk.
\end{abstract}

